\title{
Kualitas Perangkat dan Keterampilan Mengajar Mahasiswa Pendidikan Matematika pada Mata Kuliah Micro Teaching Menggunakan Analisis Model Rasch
}

\author{
Febrian $^{1 *}$, Mirta Fera ${ }^{2}$ \\ ${ }^{1,2}$ Universitas Maritim Raja Ali Haji, Kota Tanjungpinang, Provinsi Kepulauan Riau 29124, Indonesia \\ Pengiriman: 25/Februari/2019; Diterima: 23/April/2019; Publikasi: 30/April/2019 \\ DOI: https://doi.org/10.31629/jg.v4i1.1065
}

\begin{abstract}
Abstrak
Penelitian ini dilakukan untuk menganalisis kualitas perangkat dan keterampilan mengajar dengan menggunakan analisis Model Rasch. Penelitian dengan pendekatan kualitatif bersifat deskriptif ini dilakukan pada subjek penelitian mahasiswa semester V tahun akademik 2017/2018 Program Studi Pendidikan Matematika FKIP Universitas Maritim Raja Ali Haji pada mata kuliah Micro Teaching. Data yang digunakan berjenis primer/langsung yang diperoleh melalui teknik penugasan berupa perangkat pembelajaran yang terdiri atas silabus mini, Rencana Pelaksanaan Pembelajaran (RPP) mini, dan media pembelajaran. Data berikutnya diperoleh melalui observasi pada aspek keterampilan mengajar yang merupakan tolok ukur dalam proses pembelajaran. Kemudian dilakukan penilaian terhadap kedua sumber data tersebut dengan menggunakan instrumen lembar penilaian perangkat dan keterampilan mengajar yang memuat indikator-indikator terkait dengan teknik rating scale sehingga menghasilkan data ordinal. Data mentah dari kedua sumber diolah dan dianalisis menggunakan Model Rasch dengan software Ministep. Analisis yang dilakukan adalah person measure, item measure, dan person map item. Hasil analisis dipaparkan dengan teknik deskriptif kualitatif guna menggambarkan kualitas perangkat dan keterampilan mengajar. Hasil analisis perangkat diperoleh bahwa kualitas rata-rata perangkat pembelajaran disusun oleh mahasiswa berada di atas rata-rata taraf kualitas standar perangkat. Terdapat $71 \%$ dari total mahasiswa yang memiliki kualitas setiap item pada perangkat di atas rata-rata standar. Hasil analisis pada aspek mengajar diperoleh kualitas rata-rata mengajar mahasiswa lebih tinggi dari rata-rata taraf kualitas mengajar standar. Terdapat sekitar 46,4\% dari total mahasiswa yang memiliki kualitas mengajar setiap itemnya berada di atas kualitas rata-rata.
\end{abstract}

Kata kunci: kualitas; perangkat pembelajaran; keterampilan mengajar; micro teaching; model rasch

\begin{abstract}
This research was conducted to analyze the quality of teaching materials and skills using Rasch Model analysis. This descriptive qualitative research was conducted on the subject of the fifth-semester students of the 2017/2018 academic year of the Mathematics Education Study Program of Universitas Maritim Raja Ali Haji on the Micro Teaching course. The data used are primary/direct types obtained through assignment techniques in the form of teaching materials consisting of a mini syllabus, mini Lesson Plan, and learning media. Subsequent data is obtained through observation on aspects of teaching skills which are benchmarks in the learning process. Then an assessment was carried out using an instrument of assessment sheet on teaching materials and skills which contained related indicators in form of rating scale techniques so as to produce ordinal data. Raw data from both sources were processed and analyzed using Ministep-assisted Rasch Model. The analysis performed were person
\end{abstract}




\section{JURNAL GANTANG. April 2019; VOL IV(1): 87 - 95 \\ p-ISSN. 2503-0671 \\ e-ISSN. 2548-5547}

measure, item measure, and person map item. The results of the analysis are presented with qualitative descriptive techniques to illustrate the quality of the device and teaching skills. The results of the materials analysis showed that the average quality prepared by students was above the average level of standard material quality. There are $71 \%$ of students who have the quality of each item above the standard average. The results of the analysis of the teaching aspects showed that the average quality of teaching is relatively slightly higher than the average level of standard teaching quality. There are around $46.4 \%$ of the total students who have teaching qualities, each item is above average quality.

Keywords: quality; teaching materials; teaching skills; micro teaching; rasch model

\section{Pendahuluan}

Guru didefinisikan sebagai pendidik profesional dengan tugas utama mendidik, mengajar, membimbing, mengarahkan, melatih, menilai, dan mengevaluasi peserta didik pada pendidikan anak usia dini jalur pendidikan formal, pendidikan dasar, dan pendidikan menengah (UU Nomor 14, 2015). Hal ini menunjukkan profesi seorang guru memiliki kompleksitas terutama dalam hal membentuk manusia pebelajar dalam konteks pendidikan nasional. Dengan fungsinya yang beragam, dapat disimpulkan bahwa guru memiliki peran dominan dan berlaku sebagai ujung tombak pendidikan bangsa. Implikasinya, kualitas pendidikan bangsa dipengaruhi oleh kualitas para pendidiknya.

Profesi guru di Indonesia lazimnya dibentuk oleh Lembaga Pendidik Tenaga Kependidikan atau yang biasa disingkat LPTK. LPTK adalah perguruan tinggi yang diberi tugas oleh Pemerintah untuk menyelenggarakan program pengadaan guru pada pendidikan anak usia dini jalur pendidikan formal, pendidikan dasar, dan/atau pendidikan menengah, serta untuk menyelenggarakan dan mengembangkan ilmu kependidikan dan nonkependidikan (UU Nomor 87, 2013) . Hal ini mengindikasikan bahwa LPTK yang merupakan lembaga penghasil tenaga pendidik (guru) di Indonesia, sangat berperan bagi peningkatan kualitas sumber daya manusia di Indonesia (Budihardjo, 2012).

Sebagai sebuah profesi, guru dituntut memiliki sejumlah kompetensi. Kompetensi guru adalah seperangkat pengetahuan, keterampilan, dan perilaku yang harus dimiliki, dihayati, dan dikuasai oleh seorang guru dalam melaksanakan tugas keprofesionalannya (Saragih, 2008). Kompetensi guru sebagai agen pembelajaran pada jenjang pendidikan dasar dan menengah serta pendidikan anak usia dini meliputi: kompetensi pedagogik, kompetensi kepribadian, kompetensi professional, dan kompetensi sosial (PP Nomor 19 tahun 2005 pasal 28 ayat 3). Keempat kompetensi tersebut semestinya melekat secara penuh dalam diri seorang guru dan dipraktekkan sehari-hari sebagai sebuah kebiasaan.

Di samping itu, hal paling krusial yang wajib dimiliki oleh seorang guru adalah merencanakan dan melaksanakan proses pembelajaran, serta mengevaluasi hasilnya (UU Nomor 14 tahun 2015 pasal 20). Bila perencanaan dapat diartikan sebagai persiapan guru sebelum mengajar seperti kemampuan dalam menyiapkan perangkat pemebelajaran, maka pelaksanaan pembelajaran sewajarnya mengusung sebuah konsep penting pengajaran yang dikenal sebagai delapan keterampilan mengajar. Keterampilan-keterampilan ini harus dikuasai oleh guru dalam mengajar untuk dapat menciptakan pembelajaran yang efektif. Bila ditinjau dari aspek kompetensi, kemampuan ini tergolong dalam aspek pedagogik yang didefinisikan sebagai kompetensi terkait pengelolaan pembelajaran (Depdiknas, 2004:9). Untuk itu, pembekalan mengenai aspek perencaanaan dan pelaksanaan pembelajaran diikuti peninjauan mengenai kualitasnya perlu dilaksanakan. Pembekalan dan peninjauan ini 
lazimnya dilakukan terhadap calon guru di LPTK.

Universitas Maritim Raja Ali Haji (UMRAH) sebagai sebuah Perguruan Tinggi Negeri Baru (PTNB) merupakan salah satu LPTK di Indonesia yang terletak di Provinsi Kepulauan Riau. UMRAH memiliki 5 fakultas yang salah satunya adalah Fakultas Keguruan dan Ilmu Pendidikan (FKIP). Pendidikan Matematika yang merupakan salah satu program studi di FKIP UMRAH, dengan usianya yang sangat muda telah menghasilkan beberapa alumni yang dominan memilih profesi guru maupun tentor sebagai pekerjaan setelah menyelesaikan bangku perkuliahan strata 1 . Hingga tahun 2018 memiliki sejumlah mahasiswa lainnya yang telah dan akan mengikuti program pembekalan mengajar dalam mata kuliah Micro Teaching. Micro Teaching atau secara umum dikenal dengan istilah praktik pembelajaran mikro merupakan praktikum yang bersifat aplikatif dan terpadu dari seluruh pengalaman belajar sebelumnya ke dalam program pelatihan untuk menyiapkan mahasiswa agar menguasai kompetensi keguruan, sehingga dapat mengemban tugas dan tanggung jawab secara professional (Dewanti, 2012). Dengan karakternya tersebut, mata kuliah ini membuka kesempatan untuk penelusuran ataupun peninjauan mengenai kualitas perencanaan dan pelaksanaan pembelajaran oleh mahasiswa.

Terdapat studi yang mengungkap keterampilan mengajar oleh mahasiswa dalam setting Micro Teaching. Penelitian yang dilakukan Ambarawati (2016) dengan fokus pada analisis tujuh keterampilan mengajar dilakukan dengan pendekatan kualitatif deskriptif dengan teknik analisis reduksi dan peyajian data. Dalam penelitian ini ditemukan bahwa keterampilan mengajar mahasiswa berada pada penilaian baik dan sangat baik. Hasil penelitian ini mengindikasikan bahwa potensi dilakukannya analisis lebih mendalam dan representatif mengenai keterampilan mahasiswa sangatlah besar. Untuk itu sebuah studi serupa namun lebih komprehensif dirasa perlu dilakukan.

Sebuah analisis kualitas perangkat dan mengajar mahasiswa yang dijalankan dengan teknik analisis yang representatif sekiranya dapat menginformasikan sivitas akademika Program Studi Pendidikan Matematika mengenai kualitas calon guru sebelum mereka menyelesaikan perkuliahan dan siap terjun berprofesi sebagai guru atau pengajar. Di samping itu, studi ini dapat memberikan feedback kepada dosen pengajar di lingkungan Program Studi Pendidikan Matematika terkait peningkatan kualitas perkuliahan yang berkontribusi secara langsung dalam pembekalan mahasiswa menjadi calon pendidik dirasa perlu dijalankan.

Untuk melakukan analisis yang baik diperlukan sebuah alat analisis yang representatif agar dapat memberikan hasil yang akurat dan lebih reliabel terhadap kualitas perencanaan dan proses pembelajaran mahasiswa calon guru di Pendidikan Matematika FKIP UMRAH. Penelitian ini model analisis Rasch yang relatif baru dan belum banyak digunakan dalam dunia asesmen untuk menganalisis data spesifik terkait kualitas perangkat sebagai produk perencanaan pembelajaran dan keterampilan mengajar sebagai sebuah tolok ukur proses pembelajaran. Penggunaan model ini efektif karena pemodelan Rasch mengubah data skor mentah menjadi data dengan interval yang sama sehingga menghasilkan skala pengukuran yang linier, presisi dan mempunyai satuan (Sumintono \& Widhiarso, 2015). Melalui analisis model ini, kualitas perangkat dan praktek mengajar mahasiswa Pendidikan Matematika pada mata kuliah Micro Teaching dapat dideskripsikan.

\section{Metode Penelitian}

Penelitian ini mendeskripsikan kualitas perangkat dan keterampilan mengajar mahasiswa FKIP UMRAH berdasarkan hasil analisis data menggunakan model Rasch. Oleh karena itu, pendekatan penelitian yang tepat adalah pendekatan kualitatif. Sedangkan jenis penelitian yang tepat adalah penelitian deskriptif dengan metode mendeskripsikan.

Penelitian berlokasi di Kampus FKIP UMRAH Jl. Politkenik Senggarang Tanjungpinang. Subjek penelitian adalah mahasiswa Pendidikan Matematika FKIP UMRAH semester VI tahun akademik 2017/2018. Subjek dalam penelitian ini adalah 


\section{JURNAL GANTANG. Marte 2019; VOL IV(1): 31 - 35 halaman \\ p-ISSN. 2503-0671 \\ e-ISSN. 2548-5547}

mahasiswa yang mengambil mata kuliah Micro Teaching yang terbagi dalam enam kelompok mahasiswa yang akan ditinjau kualitas perangkat dan keterampilan mengajarnya.

Sumber data dalam penelitian ini dibagi

dua. Pertama, data terkait perencanaan pembelajaran, berupa perangkat pembelajaran seperti silabus mini, Rencana Pelaksanaan Pembelajaran (RPP) mini, dan Lembar Kegiatan Siswa (LKS). Definisi silabus mengacu pada Departemen Pendidikan Nasional dalam Akbar (2013) yang mendefinisikannya sebagai sebagai sebuah rencana pembelajaran pada satu dan/atau kelompok mata pelajaran/tema tertentu yang mencakup standar kompetensi/kompetensi inti dan kompetensi dasar, materi pembelajaran, kegiatan pembelajaran, indikator pencapaian kompetensi, penilaian, alokasi waktu, dan sumber belajar. Sedangkan definisi RPP yang diacu adalah berdasarkan (Ambarawati, 2016) yang mendefinisikannya sebagai pegangan bagi pengajar untuk melaksanakan proses pembelajaran di kelas yang memuat Standar Kompetensi/Kompetensi Inti yang menaungi $\mathrm{KD}$, tujuan pembelajaran, materi pembelajaran, metode pembelajaran, langkah-langkah pembelajaran, sumber belajar, dan penilaian. Selanjutnya adalah LKS yang merupakan stimulus atau bimbingan guru dalam pembelajaran yang disajikan secara tertulis berupa informasi maupun soal-soal (pertanyaanpertanyaan) dan harus dijawab oleh siswa (Astuti, Purwoko, \& Indaryanti, 2017). Kedua, data pelaksanaan/proses pembelajaran berupa keterampilan mengajar. Terdapat delapan keterampilan mengajar yang ditinjau, diantaranya keterampilan dasar bertanya, memberi penguatan, memberikan variasi, membuka dan menutup pelajaran, mengajar, mengelola kelas, membimbing diskusi kelompok kecil, dan mengajar kelompok kecil dan perseorangan (Nasution, 2015).

Data perangkat pembelajaran diperoleh dengan teknik penugasan. Dengan demikian, lembar penugasan dapat dipandang sebagai instrumen penelitian pertama. Untuk menilai kualitas perangkat maka peneliti membutuhkan lembar penilaian perangkat yang memuat kriteria-kriteria penilaian. Sedangkan data keterampilan mengajar diperoleh melalui teknik observasi langsung dengan bantuan video recorder statis. Untuk hal tersebut peneliti menggunakan instrumen lembar observasi dan penilaian keterampilan mengajar mahasiswa yang memuat kriteria terkait keterampilan mengajar. Penilaian pada perangkat dan praktek mengajar menggunakan rating scale dengan teknik skala likert $1-5 /$ poor to execellent (Vagias, 2006) yang menggambarkan level kualitas. Penilaian dilakukan oleh pakar, dalam hal ini adalah dosen-dosen pengampu mata kuliah Micro Teaching di enam kelompok mahasiswa Program Studi Pendidikan Matematika FKIP UMRAH.

Penilaian dari aspek perangkat dan praktek menghasilkan data mentah berupa data ordinal. Data mentah dari kedua sumber diolah dan dianalisis menggunakan Model Rasch dengan software Ministep. Analisis yang dilakukan adalah person measure, item measure, dan person map item. Kemudian, hasil analisis dipaparkan dengan teknik deskriptif kualitatif.

\section{Hasil dan Pembahasan}

Definisi kualitas dalam penelitian ini diturunkan dari definisi kualitas dalam konteks jasa atau pelayanan. Hal ini dianggap analogi meskipun konteks berbeda. Goetch dan Davis (1995) dalam Ariani (2014) mendefinisikan kualitas sebagai suatu kondisi dinamis yang berkaitan dengan produk, pelayanan, orang, proses, dan lingkungan yang memenuhi atau melebihi apa yang diharapkan. Sedangkan menurut perbendaharaan istilah ISO 8402 dan dari Standar Nasional Indonesia (SNI 19-84021991) dalam Ariani (2014) kualitas adalah keseluruhan ciri dan karakteristik produk atau jasa yang kemampuannya dapat memuaskan kebutuhan, baik yang dinyatakan secara tegas maupun tersamar. Objek yang dinilai kualitasnya adalah perangkat pembelajaran dan praktek mengajar mahasiswa dalam mata kuliah Micro Teaching. Kualitas dalam penelitian ini didefinisikan sebagai karakteristik perangkat dan 
mengajar yang kemampuannya dapat memuaskan serta sesuai dengan indikator penyusunan perangkat dan mengajar yang telah ditetapkan.

Kualitas Perangkat Pembelajaran

1. Tingkat Abilitas Individu (Person Measure)

Gambar 1 memberikan data mengenai kemampuan mahasiswa melalui rincian informasi logit dari tiap individu. Berdasarkan Gambar 1, mahasiswa yang memiliki level kualitas perangkat pembelajaran paling tinggi adalah 21PD dengan nilai measure (logit) sebesar +4,94, sedangkan mahasiswa yang memiliki kualitas perangkat terendah adalah 25LF dengan nilai measure (logit) sebesar -2,20.

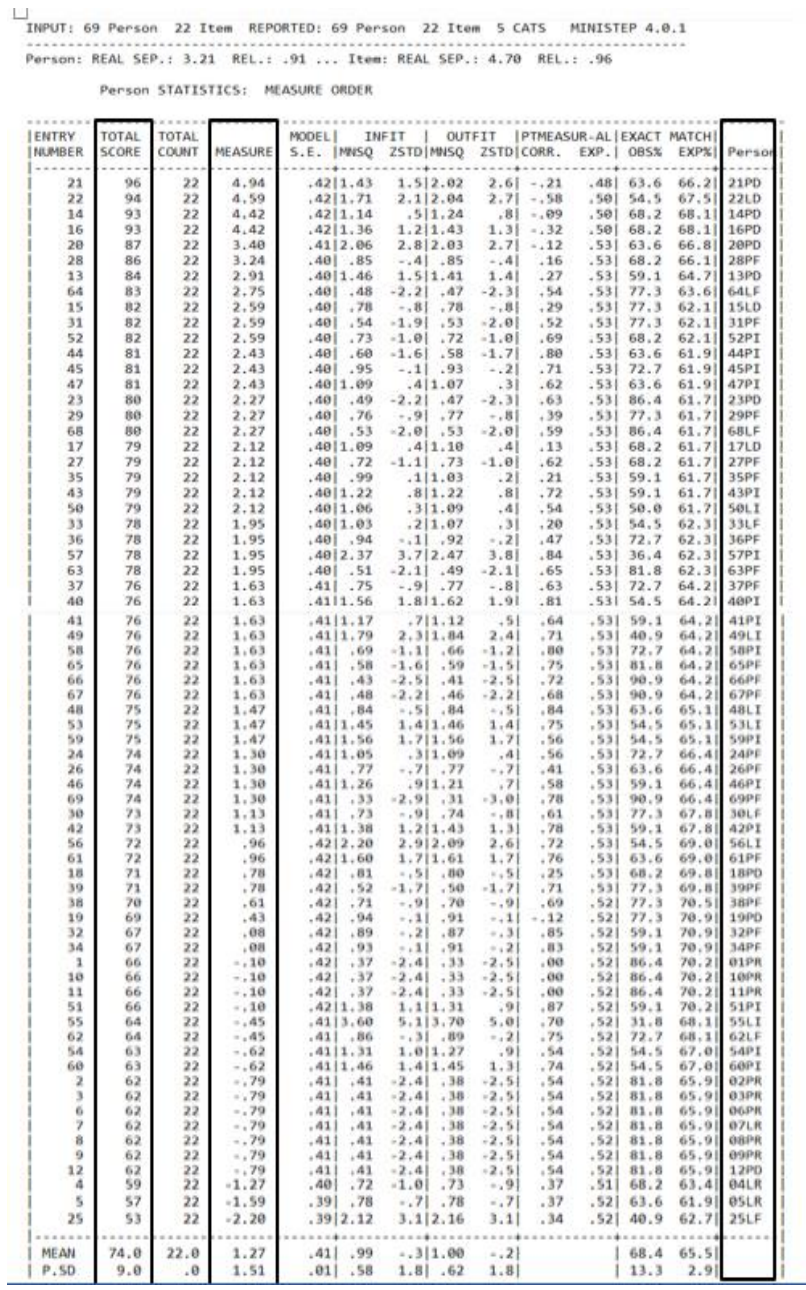

Gambar 1. Tingkat abilitas individu

\section{Tingkat Kesulitan Item (Item Measure)}

Gambar 2 memberikan data sesuai dengan urutan tingkat kesulitan penyusunan perangkat pembelajaran oleh mahasiswa pendidikan matematika dari yang sulit sampai yang mudah sesuai dengan indikator pada tiap item angket kualitas perangkat dengan melihat total skor dan nilai measure pada tiap item.

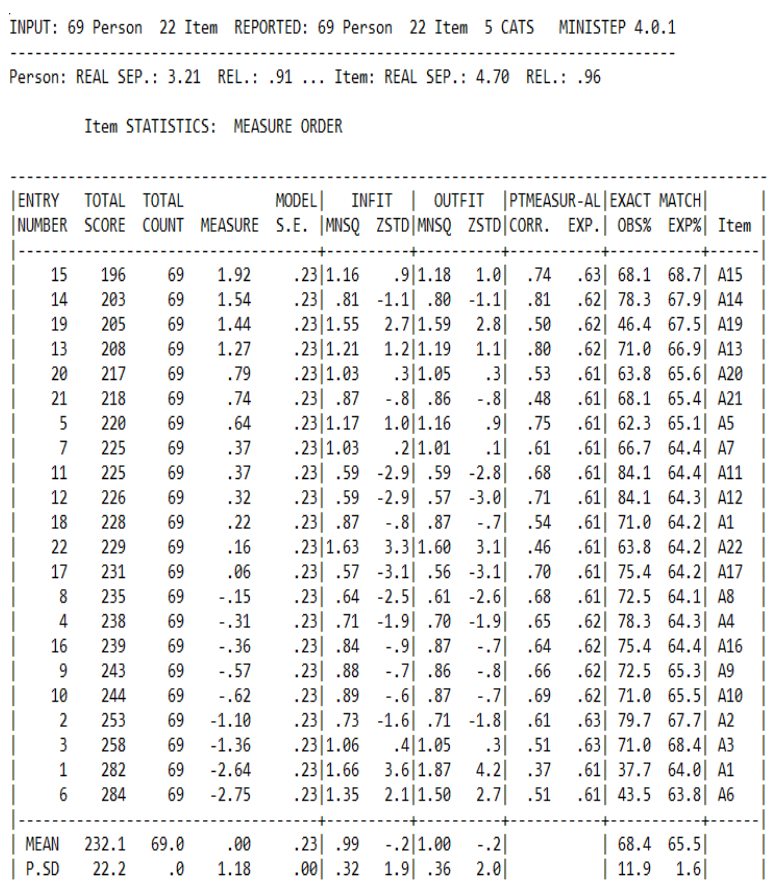

Gambar 2. Tingkat kesulitan item dalam penyusunan perangkat

Berdasarkan gambar 2, item indikator dalam menyusun perangkat pembelajaran yang paling sulit dilakukan oleh mahasiswa terdapat pada item A15, yaitu kreativitas dalam pemilihan media/alat peraga pembelajaran dengan total skor 196 dan nilai measure (logit) sebesar $+1,92$. Sedangkan item indikator dalam menyusun perangkat pembelajaran yang paling mudah dilakukan oleh mahasiswa terdapat pada item A6, yaitu penyusunan kelengkapan komponenkomponen dasar RPP (Identitas Sekolah, SK/KI, $\mathrm{KD}$, tujuan pembelajaran, indikator, materi pendukung, uraian singkat materi, strategi pembelajaran, fase pembelajaran, sumber dan alat belajar, dan penilaian) dengan total skor 284 dan nilai measure (logit) sebesar -2,75.

\section{Person Map Item}

Gambar 3 memberikan data mengenai informasi Peta Wright. Sebelah kiri menunjukkan sebaran data berdasarkan urutan mahasiswa yang memiliki kualitas perangkat pembelajaran dari yang paling tinggi, yaitu 21PD 


\section{JURNAL GANTANG. Marte 2019; VOL IV(1): 31 - 35 halaman \\ p-ISSN. 2503-0671 \\ e-ISSN. 2548-5547}

sampai mahasiswa yang memiliki kualitas perangkat pembelajaran paling rendah, yaitu 25LF. Sedangkan di sebelah kanan gambar menunjukkan sebaran data tingkat kesulitan dalam menyusun perangkat dari indikator item paling sulit, yaitu item A15 (kreativitas dalam pemilihan media/alat peraga pembelajaran) sampai yang mudah, yaitu item A6 (kelengkapan komponen-komponen dasar RPP (identitas sekolah, SK/KI, $\mathrm{kd}$, tujuan pembelajaran, indikator, materi pendukung, uraian singkat materi, strategi pembelajaran, fase pembelajaran, sumber dan alat belajar, dan penilaian).

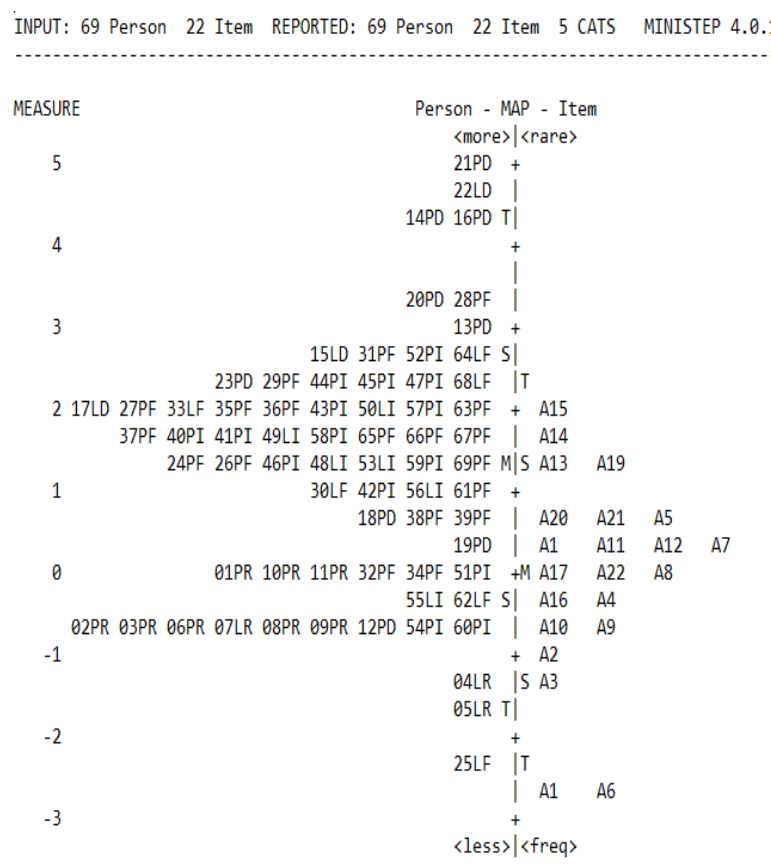

Gambar 3. Person map item dalam penyusunan perangkat

Hasil analisis Peta Wright menunjukkan bahwa terdapat 17 mahasiswa dari 69 (24,6\%) mahasiswa pendidikan matematika yang memiliki kemampuan dalam menyusun perangkat pembelajaran diatas kesulitan 22 indikator penyusunan perangkat, yaitu mahasiswa 21PD, 22LD, 14PD, 16PD, 20PD, 28PF,13PD, 15LD, 31PF, 52PI, 64LF, 23PD, 29PF, 44PI, 45PI, 47PI, 68LF. Artinya, 17 mahasiswa tersebut tidak mengalami kesulitan dalam menyusun perangkat pembelajaran sesuai dengan 22 item pada setiap indikator. Mereka mampu menyusun perangkat dengan 22 indikator yang ditetapkan dengan baik. Hal ini bermakna bahwa terdapat $24,6 \%$ mahasiswa yang dapat menyusun perangkat pembelajaran dengan kualitas yang memuaskan karena kemampuan mereka di atas kesulitan semua indikator yang telah ditetapkan.

Rata-rata logit item bernilai 0,0 logit, sedangkan rata-rata logit person $+1,18$. Hal ini menunjukkan bahwa pencapaian rata-rata mahasiswa dalam menyusun perangkat pembelajaran berada di atas rata-rata tingkat kesukaran standar penyusunan perangkat pembelajaran. Terdapat 49 mahasiswa (71\%) yang memiliki pencapaian rata-rata penyusunan perangkat pembelajaran berada di atas rata-rata tingkat kesukaran standar penyusunan. Hal ini bermakna mahasiswa secara umum mampu menyusun perangkat pembelajaran dengan baik. Item A8 (ketepatan dalam pemilihan model pembelajaran dengan sifat materi yang diajarkan), A17 (ketepatan pemilihan strategi evaluasi terkait sifat materi, proses pembelajaran, dan tujuan evaluasi), dan A22 (kejelasan kunci jawaban) berada pada 0,0 logit yang bermakna ketiga item ini memiliki tingkat kesukaran yang rata-rata. Untuk kasus ini terdapat 6 mahasiswa $(8,7 \%)$ yang memiliki prestasi rata-rata setara dengan tingkat kesukaran rata-rata item penyusunan perangkat. Terdapat 14 mahasiswa $(20,3 \%)$ memiliki pencapaian di bawah standar kesukaran rata-rata penyusunan perangkat.

Analisis Kualitas Belajar

1. Tingkat Abilitas Individu (Person Measure)

Gambar 4 memberikan data mengenai kemampuan mahasiswa melalui rincian informasi logit dari tiap individu. Berdasarkan gambar 4, mahasiswa yang memiliki level kualitas mengajar paling tinggi adalah mahasiswa dengan kode 14P dan 16P dengan nilai measure yang sama yakni sebesar 6,41 logit. sedangkan mahasiswa yang memiliki level kualitas mengajar paling rendah adalah 62L ditunjukkan dari nilai $-2,82$ logit yang merupakan nilai logit terendah. 


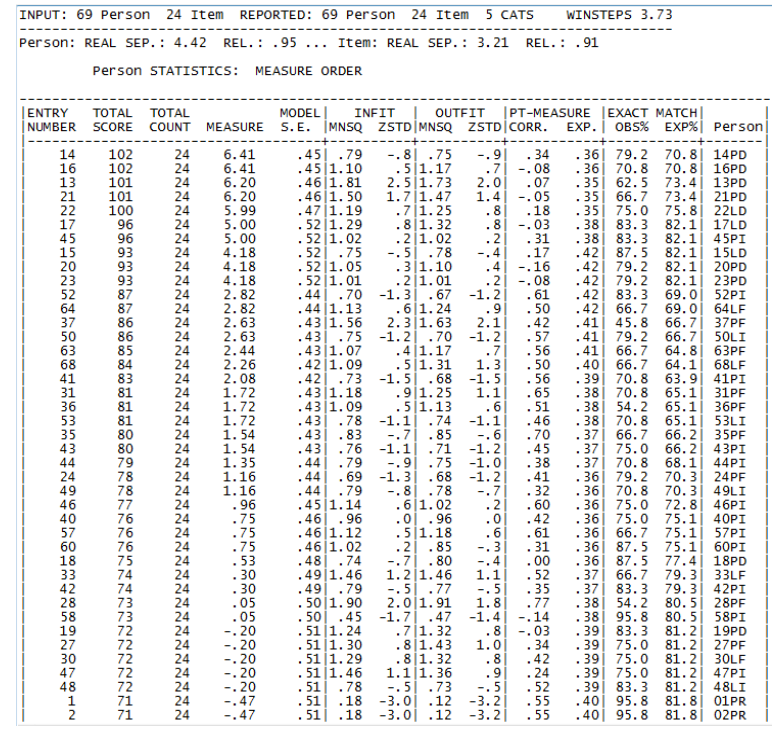

Gambar 4. Tingkat abilitas individu dalam mengajar

\section{Tingkat Kesulitan Item (Item Measure)}

Gambar 5 menunjukkan urutan butir indikator pada angket penilaian kualitas mengajar mahasiswa pendidikan matematika dari yang paling sulit hingga yang paling mudah dilakukan mahasiswa pada saat melakukan praktek mengajar (Micro Teaching).

\begin{tabular}{|c|c|c|c|c|c|c|c|c|c|c|c|c|c|}
\hline \multicolumn{14}{|c|}{$\begin{array}{l}\text { Person: ReAL SEP. }: 4.42 \text { REL. }: .95 \ldots \text { It } \\
\text { Item STATISTICS: MEASURE ORDER }\end{array}$} \\
\hline \begin{tabular}{|l} 
ENTRY \\
NUMBER
\end{tabular} & $\begin{array}{l}\text { TOTAL } \\
\text { SCORE }\end{array}$ & $\begin{array}{l}\text { TOTAL } \\
\text { COUNT }\end{array}$ & MEASURE & $\begin{array}{c}\text { MODEL } \\
\text { S.E. }\end{array}$ & MNSQ & $\begin{array}{l}\text { IFIT } \\
\text { ZSTD|M }\end{array}$ & \begin{tabular}{|l} 
OUTR \\
MNSQ
\end{tabular} & $\begin{array}{c}F I T \mid \\
\text { ZSTD|C }\end{array}$ & $\begin{array}{l}\text { PT-MEAS } \\
\text { CORR. }\end{array}$ & $\begin{array}{c}\text { SURE } \\
\text { EXP. }\end{array}$ & \begin{tabular}{|} 
EXACT \\
OBS\%
\end{tabular} & $\begin{array}{r}\text { MATCH } \\
\text { EXP\% }\end{array}$ & Item \\
\hline 13 & 185 & 69 & 58 & $26 \mid 1$ & 1.10 & .711 & 1.20 & $1.1 \mid$ & .78 & .72 & 72.5 & 69.5 & A13 \\
\hline 11 & & & & & & & & 1. & & .72 & 62.3 & & A11 \\
\hline 8 & & 69 & 1.13 & .27 & .83 & $-\left.1.0\right|^{2}$ & .83 & -.8 & .78 & .71 & 81.2 & 74.6 & $A 8$ \\
\hline 10 & & 69 & .68 & .28 & .64 & -2.1 & .62 & -1.9 & .80 & .71 & 87.0 & 75.8 & A10 \\
\hline 23 & 213 & 69 & .6 & .28 & & $.0 \mid 1$ & 1.03 & .2 & .72 & .71 & 79.7 & 75.9 & $A 23$ \\
\hline 24 & 217 & 69 & .2 & .2811 & & $2.0 \mid 1$ & 1.58 & $2.3 \mid$ & .69 & .71 & 66.7 & 76.5 & $A^{A 3}$ \\
\hline 24 & $\begin{array}{l}217 \\
219\end{array}$ & 69 & .29 & .28 & .68 & -1.8 & .69 & -1.5 & .68 & $.71 \mid$ & 84.1 & 76.5 & A24 \\
\hline 22 & ${ }_{21}^{21}$ & $\begin{array}{l}69 \\
69\end{array}$ & .13 & .28 & $\begin{array}{l}.94 \\
72\end{array}$ & $\begin{array}{r}-.2 \\
-1.5\end{array}$ & $\begin{array}{l}.89 \\
.65\end{array}$ & $\begin{array}{r}-.4 \\
-1.7\end{array}$ & .74 & .71 & $\begin{array}{l}76.8 \\
79.7\end{array}$ & $\begin{array}{l}76.8 \\
76.8\end{array}$ & $\begin{array}{l}A 2 \\
A 22\end{array}$ \\
\hline & & & .05 & .28 & .98 & $\begin{array}{r}-1.3 \\
.0\end{array}$ & .94 & $\begin{array}{r}-1.7 \\
-.2\end{array}$ & . .83 & .71 & \begin{tabular}{|l}
79.7 \\
75.4
\end{tabular} & $\begin{array}{l}76.8 \\
76.9\end{array}$ & \\
\hline 16 & & & .0 & .28 & .56 & -2.6 & .48 & -2.7 & .74 & .71 & 87.0 & 76.9 & \\
\hline 18 & 22 & & .0 & 8 & .71 & -1.5 & .74 & -1.1 & .67 & .71 & 87.0 & 76.9 & A18 \\
\hline 12 & 22 & 69 & -.1 & .28 & & -.7 & .78 & -.9 & .74 & .72 & 82.6 & 77.1 & \\
\hline 21 & 22 & 69 & -1 & .28 & 1.07 & .41 & 1.13 & .6 & .72 & .72 & 76.8 & 77.1 & A21 \\
\hline 7 & & & & 1 & 1.20 & $1.0 \mid 1$ & &. & .7 & .72 & 71.0 & 77 & \\
\hline 19 & 22 & & & & & -.3 & & -.5 & .79 & .72 & 73.9 & 77.0 & A19 \\
\hline 2 & & & & & 1.23 & $1.2 \mid 1$ & 1.33 & 1.4 & .03 & .72 & $\mid 69.6$ & 76.6 & $A 20$ \\
\hline${ }_{14}^{4}$ & 22 & 69 & -.6 & .28 & .49 & -3.2 & & -3.5 & .83 & .72 & 88.4 & $76.4 \mid$ & A4 \\
\hline 14 & 23 & 69 & -.7 & .2811 & 1.14 & $.8 \mid 1$ & 1.22 & 1.0 & .59 & .72 & 75.4 & 76.3 & A14 \\
\hline 17 & 23 & & -.7 & .28 & & -1.5 & & -1.2 & .72 & .72 & 84.1 & 76.3 & A17 \\
\hline $\begin{array}{r}9 \\
15\end{array}$ & $\begin{array}{l}233 \\
233\end{array}$ & 69 & -.9 & .281 & 1.17 & .911 & 1.22 & 1.0 & .59 & .72 & 75.4 & $\begin{array}{l}75.6 \\
75.6\end{array}$ & ${ }^{A 9}$ \\
\hline & 23 & & & .2811 & & .21 & & 1. & .6 & .72 & & 75.6] & \\
\hline r & 240 & 69 & -1.52 & $.27 / 1$ & 1.42 & $\begin{array}{l}1.021 \\
2.2\end{array}$ & 1.33 & $1.6 \mid$ & .58 & & 71.0 & $74.0 \mid$ & \\
\hline & & & & & & & & & & & & & \\
\hline & & & & & 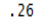 & & & & & & 0.0 & & \\
\hline
\end{tabular}

Gambar 5. Tingkat kesulitan item dalam mengajar

Berdasarkan data pada gambar 5, dapat disimpulkan bahwa indikator penilaian perangkat mengajar yang paling sulit dilakukan oleh mahasiswa pendidikan matematika adalah indikator A13 yaitu penggunaan penguatan nonverbal/gesture dengan total skor sebesar 185 dari total score maksimalnya adalah 345 dan nilai measure 2.58 logit. selanjutnya untuk indikator pada angket penilaian kualitas mengajar yang paling mudah atau dikuasai oleh mahasiswa pendidikan matematika pada saat melakukan praktek mengajar adalah indikator A1 yaitu aspek membuka pelajaran yakni dapat menarik perhatian siswa dengan total skor 240 dari total skor maksimumnya 345 dan nilai measure -1.52 logit.

\section{Person Map Item}

Gambar 6 memberikan informasi mengenai Peta Wright, sebelah kiri menggambarkan sebaran kemampuan mahasiswa berdasarkan kualitas praktek mengajar dari yang tertinggi dilihat dari nilai logitnya hingga mahasiswa yang memiliki kemampuan praktek mengajar terendah dan sebelah kanan menggambarkan sebaran tingkat kesulitan butir pada indikator penilaian kualitas praktek mengajar yang diurutkan dari indikator yang tersulit untuk dilakukan mahasiswa pada saat praktek mengajar yaitu indikator A11 (penerapan skill classroom questioning dengan tujuan yang jelas dan teknik yang tepat) dan A13 (penggunaan penguatan non-verbal/gesture) hingga butir indikator yang termudah yakni A1 yaitu aspek membuka pelajaran yakni dapat menarik perhatian siswa.

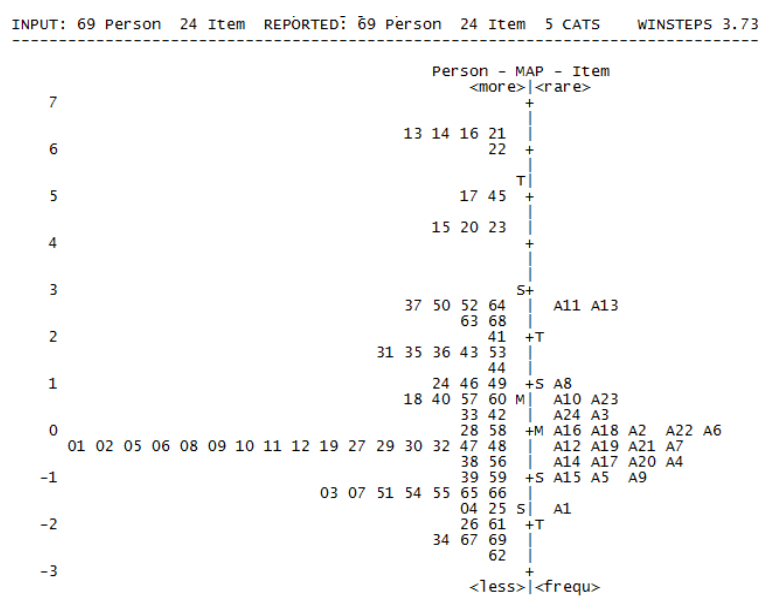

Gambar 6. Person map item pada aspek mengajar

Hasil analisis melalui peta Wright ini menunjukkan bahwa dari 69 mahasiswa pendidikan matematika, hanya ada 10 mahasiswa $(14,5 \%)$ yang memiliki kemampuan mengajar diatas kesulitan 24 indikator pada angket penilaian kualitas mengajar yakni 


\section{JURNAL GANTANG. Marte 2019; VOL IV(1): 31 - 35 halaman \\ p-ISSN. 2503-0671 \\ e-ISSN. 2548-5547}

mahasiswa dengan kode $13,14,16,21,22,17$, $45,15,20$, dan 23. Artinya 10 mahasiswa tersebut tidak mengalami kesulitan dan mudah memperoleh level kualitas yang memuaskan pada setiap kegiatan berdasarkan indikator penilaian kualitas mengajar. Adapun 6 dari 69 mahasiswa $(8,7 \%)$ mahasiswa yang memiliki kemampuan terendah adalah mahasiswa dengan kode 26, 61, 34, 67, 69 dan 62 dengan nilai logit lebih kecil dari -2 logit dan berada di bawah logit indikator penilaian perangkat mengajar. Artinya, mahasiswa tersebut akan mengalami kesulitan melakukan kegiatan tiap indikator dan sulit pula untuk memperoleh skor maksimal pada tiap indikator penilaian kualitas mengajar.

Rata-rata logit item bernilai 0,0 logit, sedangkan rata-rata logit person bernilai $+0,98$. Hal ini bermakna bahwa pencapaian rata-rata mahasiswa dalam mengajar berada sedikit di atas rata-rata tingkat kesukaran item mengajar. Terdapat 32 dari 69 mahasiswa $(46,4 \%)$ yang memiliki pencapaian rata-rata di atas rata-rata tingkat kesulitan item mengajar. Hal ini bermakna kurang dari setengah dari total mahasiswa mampu menyajikan pengajaran dengan kualitas yang baik. Item A2 (penyampaian apersepsi), A6 (kemampuan menjelaskan materi), A16 (variasi titik perhatian), A18 (variasi penugasan), dan A22 (menciptakan kondisi belajar optimal) merupakan item-item mengajar dengan kesukaran rata-rata. Untuk kasus ini, terdapat 2 dari 69 mahasiswa (2,9\%) yang memiliki pencapaian rata-rata setara dengan tingkat kesukaran rata-rata item mengajar. Terdapat 35 mahasiswa $(50,7 \%)$ memiliki pencapaian mengajar di bawah rata-rata standar mengajar.

Hasil menunjukkan bahwa analisis kualitas dan perangkat yang dilakukan dengan menggunakan model Rasch ini tidak hanya mampu memetakan kemampuan mahasiswa dalam menyusun perangkat dan menjalankan keterampilan mengajar dengan baik. Hasil analisis ini relatif representatif mengingat hasil analisis juga dapat memetakan keterkaitan antar kemampuan dan kualitas mahasiswa. Hal ini memungkinkan untuk melakukan pemeringkatan kualitas secara objektif. Hal ini sejalan dengan pendapat Sumintono \& Widhiarso (2015) yang menyatakan bahwa dalam penilaian pendidikan yang dilakukan dengan rasch model akan mempunyai kualitas yang sama seperti halnya pengukuran yang dilakukan dalam dimensi fisik dalam bidang fisika sehingga hasil pengukuran objektif.

\section{Kesimpulan}

Berdasarkan hasil analisis perangkat melalui pendekatan person measure, item measure, dan persebaran person-map diperoleh bahwa kualitas rata-rata perangkat pembelajaran disusun oleh mahasiswa berada di atas rata-rata taraf kualitas standar perangkat. Terdapat $71 \%$ dari total mahasiswa yang memiliki kualitas setiap item pada perangkat di atas rata-rata standar. Sedangkan berdasarkan hasil analisis pada aspek mengajar melalui pendekatan person measure, item measure, dan persebaran person map, diperoleh bahwa kualitas rata-rata mengajar mahasiswa lebih tinggi dari rata-rata taraf kualitas mengajar standar. Terdapat sekitar $46,4 \%$ dari total mahasiswa yang memiliki kualitas mengajar setiap itemnya berada di atas kualitas rata-rata.

Ketepatan dalam pemilihan model pembelajaran dengan sifat materi yang diajarkan, ketepatan pemilihan strategi evaluasi terkait sifat materi, proses pembelajaran, dan tujuan evaluasi, dan kejelasan kunci jawaban merupakan item dalam penyusunan perangkat yang memiliki taraf kesulitan rata-rata bagi seluruh mahasiswa. Sedangkan penyampaian apersepsi, kemampuan menjelaskan materi, pengadaan variasi titik perhatian, variasi penugasan, dan menciptakan kondisi belajar optimal merupakan item-item mengajar dengan taraf kesulitan rata-rata bagi seluruh mahasiswa.

\section{Ucapan Terimakasih}

Terimakasih yang sebesarnya kepada Universitas Maritim Raja Ali Haji yang telah mendanai kegiatan penelitian dalam skema Penelitian Dosen Muda Hibah Penelitian Internal UMRAH tahun 2018. Terimakasih juga ditujukan kepada tim penilai perangkat dan mengajar mahasiswa 
pada mata kuliah Micro Teaching Tahun Akademik 2017/2018, serta alumni Program Studi Pendidikan Matematika Angkatan 2015/2016 atas nama Ismi Badriah, S.Pd. dan Susdelina Sinaga, S.Pd. yang telah membantu peneliti dalam pengolahan data.

\section{Referensi}

Akbar, S. 'dun. (2013). Instrumen Perangkat Pembelajaran. PT Remaja Rosdakarya.

Ambarawati, M. (2016). Analisis keterampilan mengajar calon guru pendidikan matematika pada matakuliah micro teaching. Pedagogia: Jurnal Pendidikan, 5(1), 81-90.

Ariani, D. W. (2014). Manajemen Kualitas.

Astuti, P., Purwoko, P., \& Indaryanti, I. (2017). Pengembangan LKS untuk melatih kemampuan berpikir kritis dalam mata pelajaran matematika di kelas VII SMP. Jurnal Gantang, 2(2), 145-155.

Budihardjo, A. H. (2012). Peran LPTK dalam pengembangan pendidikan vokasi di Indonesia. Prosiding Aptekindo, 6(1).

Dewanti, S. S. (2012). Analisis kesiapan mahasiswa program studi pendidikan matematika sebagai calon pendidik profesional. In Seminar Nasional Pendidikan Matematika Surakarta.

Indonesia, P. R. (2005). Peraturan Pemerintah Republik Indonesia nomor 19 tahun 2005 tentang standar nasional pendidikan. Departemen Pendidikan Nasional Republik Indonesia.

Nasution, M. (2015). Dasar-dasar keterampilan mengajar matematika. Studi Multidisipliner: Jurnal Kajian Keislaman, 1(1), 89-104.

Nomor, U.-U. R. I. (14). tahun 2005 tentang Guru dan Dosen.

Saragih, A. H. (2008). Kompetensi minimal seorang guru dalam mengajar. Jurnal Tabularasa, 5(1), 23-34.

Sumintono, B., \& Widhiarso, W. (2015). Aplikasi Pemodelan RASCH pada Assessment Pendidikan (I). Trim Komunikata.

Vagias, W. M. (2006). Likert-type Scale Response Anchors. Clemson
International Institute for Tourism. \& Research Development, Department of Parks, Recreation and Tourism Management, Clemson University. 
JURNAL GANTANG. Marte 2019; VOL IV(1): 31 - 35 halaman p-ISSN. 2503-0671

e-ISSN. 2548-5547 